\title{
Children's Sophisticated Use of Digital Technology
}

Seçil Yücelyiğit ${ }^{1}$

\section{Type/Tür:}

Research/Araştırma

Received/Geliş Tarihi: July 25/

25 Temmuz 2020

Accepted/Kabul Tarihi: October 15/ 15 Ekim 2020

Page numbers/Sayfa No: 781-798

Corresponding

Author/İletişimden Sorumlu

Yazar: secil.yucelyigit@gmail.com

\section{$\checkmark$ iThenticate}

This paper was checked for plagiarism using iThenticate during the preview process and before publication. / Bu çalışma ön inceleme sürecinde ve yayımlanmadan önce iThenticate yazılımı ile taranmıştır.

Copyright $(\mathcal{C} 2017$ by

Cumhuriyet University, Faculty of Education. All rights reserved.
Neriman Aral ${ }^{2}$

\begin{abstract}
The literature about digital media and technology usage of children has two faces. On one side, the production-oriented sophisticated use of digital devices is reported while on the other side it is a source of concern due to excessive and pointless use. Some of the children are tech-consumers in terms of using their digital devices and some children use them beneficially. This qualitative study adopts phenomenological approach, with a focus to draw a conclusion for educators and aims to shed light on the technological device use of children in terms of duration, purpose, preferences, and feelings about their usage. A total of 61 children aged 7-15 years participated in the study. The children were from different backgrounds such as different parts of the country, different types of schools and different socio-economic levels. Identifying the similarities and differences of the characteristics of their usage is thought to reveal the factors that motivate the beneficial use of digital technology or that lead to consumption as a means of leisure time tool. The findings of this study enable to provide recommendations to teachers to guide students in the beneficial use of technology. Furthermore the study has some suggestions in a wider scope of the implications for practice and/or policy.
\end{abstract}

Keywords: Digital technology, sophisticated use, productionoriented use, digital consumption, technology and children

\section{Suggested APA Citation/Önerilen APA Atıf Biçimi:}

Yücelyiğit, S., \& Aral, N. (2020). Children's sophisticated use of digital technology. Cumhuriyet International Journal of Education, 10(2), 781-798. http://dx.doi.org/10.30703/cije.773845

\footnotetext{
1 Dr. Öğr. Üyesi, TED Üniversitesi, Eğitim Fakültesi, Temel Eğitim Bölümü, Ankara/Türkiye Asst. Prof., TED University, Faculty of Education, Department of Basic Education, Ankara/Turkey e-mail: secil.yucelyigit@gmail.comＯRCID ID: orcid.org/ 0000-0002-6886-5997

2 Prof. Dr., Ankara Üniversitesi, Sağlık Bilimleri Fakültesi, Çocuk Gelişimi Bölümü, Ankara/Türkiye Prof. Dr., Ankara University, Faculty of Health Sciences/Department of Pediatric Development, Ankara/Turkey e-mail: aralneriman@gmail.comＯRCID ID: orcid.org/,0000-0002-9266-938X
} 


\title{
Çocukların Dijital Teknolojiyi Üretim Odaklı Gelişmiş Amaçlarla Kullanmaları
}

\begin{abstract}
Alan yazında çocukların dijital teknoloji kullanımı iki yönlü ele alınmaktadır. Bir tarafta, dijital cihazların üretim odaklı ve gelişmiş amaçlarla kullanımı bildirilirken, diğer tarafta aşırı ve gereksiz kullanımı kaygıya neden olmaktadır. Çocuklardan bazıları dijital cihazlarını kullanma konusunda sosyal medya takibi örneğinde olduğu gibi tüketimden öteye geçemezken, bazı çocuklar ise dijital cihazlarını kodlama, üç boyutlu tasarım, dijital kitap, oyun yazma gibi üretim amacıyla kullanmaktadır. Bu nitel çalışma, eğitimciler için sonuç çıarmaya odaklanarak fenomenolojik yaklaşımı benimsemiştir ve çocukların dijital cihazlarını kullanım süresi, amacı, tercihleri ve bu cihazları kullanırken ya da dijital cihazlara ulaşamadıkları durumlardaki duygularını derinlemesine inceleyerek çocukların teknolojik cihaz kullanımı olgusuna ışık tutmayı amaçlamaktadır. Çalışmaya 7-15 yaş arası toplam 61 çocuk katılmıştır. Çocuklar, ülkenin farklı bölgeleri, farklı okul türleri ve farklı sosyo-ekonomik seviyelerinden gelmektedir. Araştırmaya katılan farklı özelliklere sahip çocukların dijital cihaz kullanımlarının benzerlik ve farklılıklarının tespit edilmesinin, dijital teknolojinin faydalı kullanımını motive eden veya boş zaman aracı olarak tüketime yol açan faktörleri ortaya çıkarabileceği düşünülmektedir. Araştırma bulguları çocukların bilgisayar ve tablet kullanımlarının okul, kişisel gelişim ve eğlence olmak üzere üç ana başlık altında toplandığını, telefon kullanımlarının ise iletişim ve eğlence olmak üzere iki başlık altında toplandığını göstermektedir. Bu çalışmanın bulguları öğretmenlere, öğrencilere teknolojinin faydalı kullanımı konusunda rehberlik etmeleri için önerilerde bulunulmasını sağlamaktadır. Ayrıca, çalışma uygulama ve / veya politika için daha geniş bir kapsamda öneriler sunmaktadır.
\end{abstract}

Anahtar Kelimeler: Dijital teknoloji, sofistike kullanım, üretim odaklı kullanım, dijital tüketim, teknoloji ve çocuk.

\section{Introduction}

There are many studies in the literature on educational research that underline the necessity and importance of integrating technology into learning and teaching. Some of these studies aim to identify the tools and strategies to meet the need for technologysupported education at different levels and in different subject areas and some aim to demonstrate the impact of the determined strategies and developed tools (Altun, 2018; Aydın, 2017; Koçak, Yılmaz, Küçük and Göktaş, 2019; Vesisenaho, Dillon, HavuNuutinen, Nousiainen, Valtonen and Wang, 2017; Shieh and Yu, 2016; Yelland, 2018). As a further step ahead in current position of technology-enhanced education studies, it is thought that production-oriented use of technology in education will contribute to the field. In this study, based on the definition of Beetham and Sharpe (2007), the sophisticated use of digital technology is evaluated within the framework of production and development. Generating computer programs or 3D models, e-book production and producing digital art can be given as an example for productive-use of digital devices. When the current studies are analysed, very limited results are encountered (Özdemir, Çetin, Çelik, Berikan and Yüksel, 2017) with the focus on the sophisticated use of technology such as production-oriented use for educational purposes.

Children are subject to new media or technologies, such as smartphones, tablets, and mobile apps, starting from a very early period in their lives. In this study 'technology use', 'use of digital media' or 'digital media and technology' refer to computer, tablet and smartphone usage. We are in a period during which progress 
means a rapid transformation of knowledge and skill into implementation and production. This cycle requires individuals who are interested in producing through innovation. Countries make policies for their future to increase the interest of their new generation in producing new technologies. However, there is a large concern about technology use of children in negative ways. Studies examining the risks of the digital technology usage identifies the online risks and emphasize measures to be taken (Blum-Ross and Livingstone, 2016; Kabakçı Yurdakul and Odabaş1, 2017; Yaman, Dönmez, Aral and Doğan Keskin, 2018), while the studies presented from the perspective of educational technologies share the positive outcomes of using technology in ideal conditions (Fessakis et. al, 2013, McPake et.al, 2013, Mills, 2011). Blended quantitative and qualitative evaluations should be made from a multidimensional perspective in order to spread the sophisticated examples about technology use of children.

Both the observations and the research results illustrate that children begin using technological devices even before they celebrate their first birthdays. A study by Hilda et al. (2015) reveals that almost all of the children in their study group have access to digital devices, and three-fourths of them have their own mobile devices at age four. Most of the research results agree that well-planned and appropriately selected technology use has a positive effect on the various areas of a child's development. Choi and Kirkorian (2016) suggest that contingent interaction designed to emphasize specific information on a screen may promote learning. De Jong and Bus (2004) noted that kindergarten children who have listened to a story from an electronic device independently are more likely to retell the story than if they had heard the story from an adult. Neumann and Neumann (2014) suggest that touchscreen devices have the potential to enhance early literacy skills, but this finding is due to the quality of the apps used for this aim. Empirical studies by Yücelyiğit and Aral (2013, 2016, 2017a) reveal that $3 \mathrm{D}$ animated movies and interactive applications with touchscreen devices generate a significant effect on visual perceptual skills, such as spatial relations, form constancy and figure-ground discrimination. Findings of Dejonckheere et al. (2014) show that there is a relationship between motor development and math skills, and researchers highlight the use of action-based digital tools such as touchscreen devices to support the mathematical skills of children with low motor capability. Simpson, Walsh, and Rowsell (2013) report that the integration of tablet technologies into the literacy lessons of seven- and eight-year-old children living in Canada and Australia help children not only with their interaction but also with collaborative and participatory learning. The number of studies that reveal the contribution of technology driven implementations on the learning or development of children are increasing day by day.

The cautions concerning technology usage and screen time include both physical (Wiecha et al., 2006, Torsheim et al., 2010) and psychological (APA, 2015) pathologies, such as obesity, spinal damage, vision problems, irregular sleep patterns, attention problems, violent behaviour, a decrease in academic performance, and antisocial behaviours. Despite concerns among parents and educators, the amount of empirical evidence of the adverse impacts of technology on children is minimal. Some experts find it is insufficient to blame technology for all undesirable results. They emphasize content instead of format (Wainwright and Linebarger, 2009). The findings 
by Periathiruvadi and Rinn (2012) indicate that gifted students reported positive perceptions about using technology for learning in different areas, including math, science, and literature. Samuelsson (2010) claims that the purpose of IT use among 13year-old Swedish children are mostly for fun and entertainment. In their study, Foen, Zakaria, Lai, and Confessore (2016) ascertained that the time allocated for non-schoolrelated activities such as Internet surfing, social media activities and video gaming was correlated negatively with academic achievement, but the correlation was not significant.

The international organizations such as the EU, OECD, UNICEF and national institutions presented the research results mirroring the current situation on technology use of children. OECD (2012) report revealed that children spend more time on the Internet than before since 2005. The Turkish National Statistics Institution reported (TUIK, 2014) that in $201360 \%$ of Turkish children between the ages 6-15 used computers, $50 \%$ of them used the Internet and $24 \%$ used mobile phones. According to the Global Digital Report 2018, the number of children between 5-14 years old who use the Internet is more than one billion (We Are Social, 2018) and in 2019 it is reported that the world's average internet use is 6 hours 42 minutes (We Are Social, 2019). The purpose of the Internet use among children varies from region to region. According to the Kaspersky Lab Report, covering the 12 months from May 2016 to April 2017, the majority of the children in the world who use the Internet mostly for communication (social media, messaging or e-mailing) is the Middle Eastern children with $89 \%$ rate. The North American children constitute the opposite peak with $28 \%$ rate. The statistics of the Internet use for Turkish children with the purpose of communication is $70 \%$ which is below the Middle East but above the world average. The report reveals that the highest rate for e-commerce is obtained from the Far Eastern children (China, Singapore, Hong Kong, Macau, Taiwan, Japan and South Korea) with 13\% which is over the world average of 5\%. Western European children use Internet for game category and alcohol-tobacco-narcotics category with high rates following the North American and Oceanian children (Kaspersky Lab Report, 2017). Organizations are discussing how ICT can be leveraged to reduce the potential risks and to accelerate the achievements of education. International Forum on ICT and Education 2030, organized by UNESCO, aims to explore the new digital innovations for best school practices, formulate partnerships and develop action plans to transform the education provision and share national policies among its partners (UNESCO, 2017).

Teachers, educators, parents, and policymakers share a responsibility to protect children from the risks stemming from the use of technology and to provide the appropriate circumstances for its beneficial use. Since building a future without emerging technologies is inconceivable, it will be reasonable to involve children efficiently in technological progress. The responsibilities of parents and educators are to use digital devices appropriately to enhance their children's cognitive and social abilities and to raise awareness of misuse and/or overuse of technology. There are programmes developed by specialists that instruct children on how to productively use the technology that surrounds them. Not all children have the opportunity to participate in a programme such as this, although every child deserves it, since the number of programmes in this classification is not sufficient. Giving children the chance to be productive in using technology can be achieved by motivating them in 
new technologies. In this context, it is critical to determine the basis of children's interest in their usage of technology. This study intends to analyse the duration and scope of the use of technology among children, the data surrounding their interests, and the distinct characteristics influencing their technological preferences. Aiming to define the diversity in children's use of digital media and technologies, the study searches for if children's use of digital devices produce different results.

\section{Research Design}

\section{Methodology}

This qualitative study adopted phenomenological approach. As Patton (2014, p.104) defines "... a phenomenological study... is one that focused on descriptions of what people experience and how it is that they experience what they experience." In this study, the lived experience is children's use of digital devices, how they feel when they are engaged in and how they feel when they have no access to their digital devices. The data were collected via personal information and semi-structured interview forms to obtain an in-depth understanding of technology use among children. The thematic analysis methodology was employed for data analysis. This method employs a systematic research to enable a technique for the qualitative analysis of information and provides a detailed and nuanced account of data (Ward, 2012). The study aims to achieve results through collection of open-ended qualitative data, to explore and obtain a depth of understanding regarding the diversity and characteristics of the use of digital devices among children.

\section{Participants}

The participants in the study constitute deviant case (outlier) sampling which is one of the purposeful sampling strategies. Purposeful sampling is a technique widely used in qualitative research for the identification and selection of information-rich cases (Patton, 2014). Deviant case design provides to illuminate both the unusual and typical cases that guide future research and practice. To determine the similarities and differences explored in this research, different samples were chosen purposefully, and interviews were held with different groups of children. A total of 61 children aged 715 years participated in the study. The children were from different backgrounds such as different parts of the country, different types of schools and different socioeconomic levels. The diversity of the school types of the participants is based on their affiliation (state or private), their program types (regular school, vocational school or Anatolian high school) and their regional location (Ankara or Muğla). For school diversity, different school types were included in the research intentionally. The variety of school types from different cities and socio-economic regions provided a diversity in the sample which enriches the study with its results from a wide range of perspectives. Some of the children had meaningful experiences with their digital devices such as using them purposefully for 3D modelling, coding or robotics. Some children showed no particular interest for 3D modelling, coding or robotics as reported by their parents, teachers or by themselves. The consent of the parents was collected before the interviews with children. All children declared that their participation in this study was on a volunteer basis. The information of the participants about their gender, class level, school types based on their affiliation and program are listed in the table below. 
As seen in Table 1, the majority of the participants are boy (72\%), 15 years old $(52 \%)$, attending 5 th -9 th classes and from state schools $(61 \%)$ with regular school programs (49\%).

Table 1

Age, Gender, Class Level and School Type of Participants (n=61)

\begin{tabular}{lllllc}
\hline Age & $\mathrm{f}$ & $\%$ & School type based on program & $\mathrm{f}$ & $\%$ \\
\hline 7-10 years & 9 & 15 & Vocational high school & 16 & 26 \\
11-12 years & 11 & 18 & Anatolian high school & 15 & 25 \\
13-14 years & 9 & 15 & Regular school & 30 & 49 \\
15 years & 32 & 52 & & & \\
Total & 61 & 100 & Total & 61 & 100 \\
\hline Gender & $\mathrm{f}$ & $\%$ & School type based on affiliation & $\mathrm{f}$ & $\%$ \\
\hline Girl & 17 & 28 & State school & 37 & 61 \\
Boy & 44 & 72 & Private school & 24 & 39 \\
Total & 61 & 100 & Total & 61 & 100 \\
\hline Class Level & $\mathrm{f}$ & $\%$ & & & \\
\hline 1-4 class level & 9 & 15 & & & \\
5-9 class level & 52 & 85 & & & \\
Total & 61 & 100 & & & \\
\hline
\end{tabular}

\section{Data Collection}

The data for the study were obtained using a personal information form and the faceto-face interview method. Face-to-face interview is a common method in social sciences, as they provide rich data comprising of nuances and depth via experiences, attitudes, feelings, beliefs, emotions, and opinions (Briggs, 1986). Researchers designed a personal information form to collect the demographic information about children. The forms were sent to parents and collected along with their consent. A semistructured interview form was used during the interviews to obtain children's opinions on their use of technology. The interview forms were prepared following a literature review and pre-interviews with the children. Next, in line with this groundwork, the questions were designed. Children were asked the digital devices they own and share at home, duration of their usage of them, the purpose of their usage, their feelings during the interaction with the device and in case they do not have access to them. The semi-structured interview form was reviewed by child development specialists and technology experts and then finalized according to their feedback. The pilot study was conducted with two child, one of whom had a special interest in productive use of digital devices and the other did not. The children reported that they had no difficulties in responding to the interview questions. The questions asked to the children were presented in Table 2. 
Table 2

Questions asked to children about their digital device use

1. Which digital devices do you have at home? Do you own them in private or share them with family members?

2. What is the approximate duration of your usage for each of the digital device in a typical weekday? Does this duration differ at weekend? How?

3. What type of programs/applications do you use when you are spending time with your digital device?

4. How do you feel while using your digital devices?

5. How do you feel when you don't have access to your digital devices?

The interview session occurred between July 2017 and February 2018. Each interview lasted approximately 30 minutes. During the interviews, an observer accompanied the researcher. The researcher asked the questions in the semi-structured interview form and took notes during the sessions. After every interview session, the recorded perspectives of each participant were evaluated by the researcher and the observer together with a consensus to avoid any bias in their views.

\section{Data Analysis}

Following all the interviews, the children's responses to the survey and interview questions were saved digitally on a computer without any alteration or correction. The participants were indexed as $\mathrm{C} 1, \mathrm{C} 2, \ldots$ to $\mathrm{C} 61$ for the confidentiality of personal information so that the names remained anonymous. The answers to the open-ended questions were coded. Coding refers to the identification of topics, issues, similarities, and differences revealed through the participants' narratives (Sutton and Austin, 2015). To establish coding credibility, another researcher was asked to code the same data. The researchers discussed the similarities and differences between the two sets of codes for credibility and reached a consensus on internal and external data consistency. For the thematic analysis of the data, MaxQDA qualitative data analysis software was used.

\section{Findings}

The results of the study investigating digital technology use by children are presented below with the interview questions and the answers to the questions. The answers of the children to the first question show that most of the children in the study group own their private computers (\%46), and smartphones (\%87) while most of them share the tablet (\%52) with family members. Among the three digital devices, smartphone is the most possessed one (\%87) in the study group. The answers to the second question 'What is the approximate duration of your usage for each of the digital device in a typical weekday?' reveal that the majority $(43 \%)$ using computers reported an exposure time of one to two hours a day; the majority (39\%) using a tablet reported an exposure time of less than an hour a day, and the majority $(47 \%)$ using smartphones reported an exposure time of more than three hours a day. Nevertheless, there are children who use their computer from four to six hours a day, their tablet two hours per day and their smartphone perpetually during the day. The duration shared in the table is given for a typical weekday. Children reported longer weekend usage durations, but they avoided articulating specific periods and their answers remained 
unclear for weekend usage. Figure 1 presents the related results for weekdays in graphics.

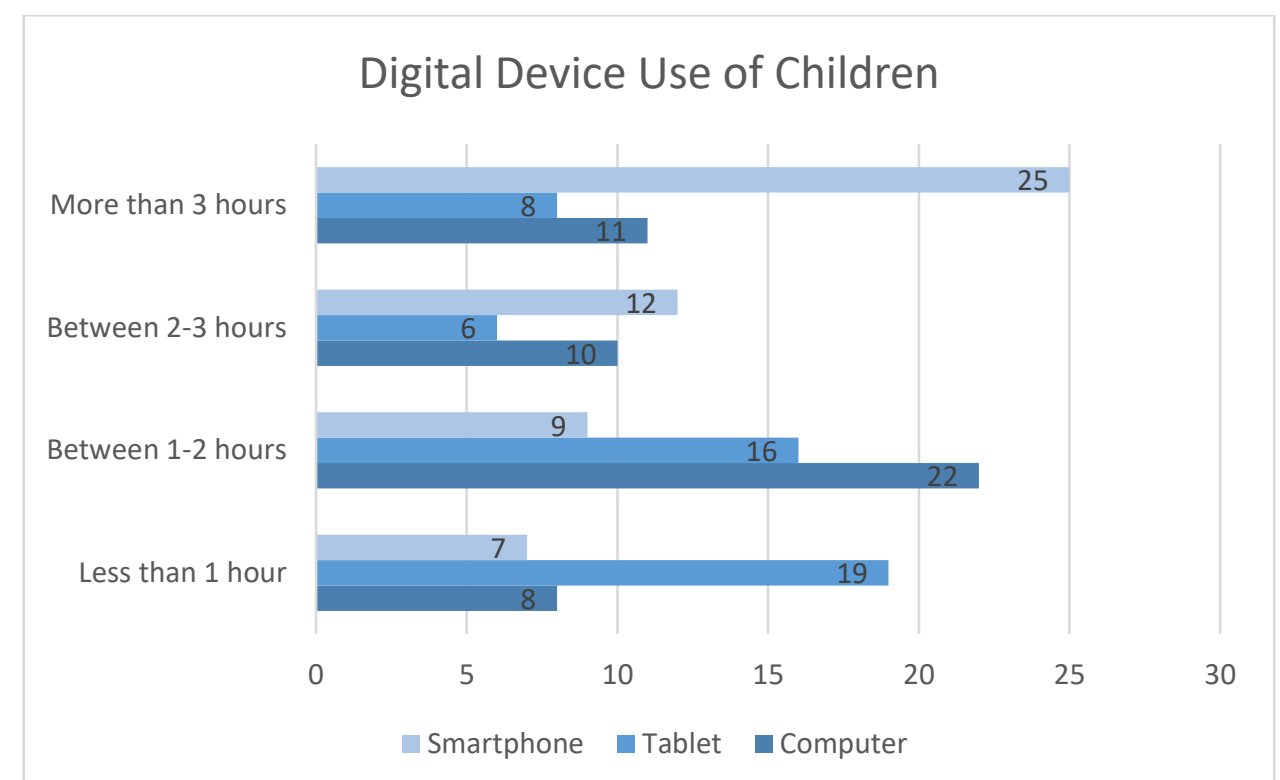

Figure 1. Approximate duration of children's usage of their digital devices in a typical weekday in graphics.

The children were then asked 'What type of programs/applications do you use when you are spending time with your digital device?'. Their answers were categorized drawn on the coding process, as shown in Figure 2 below.

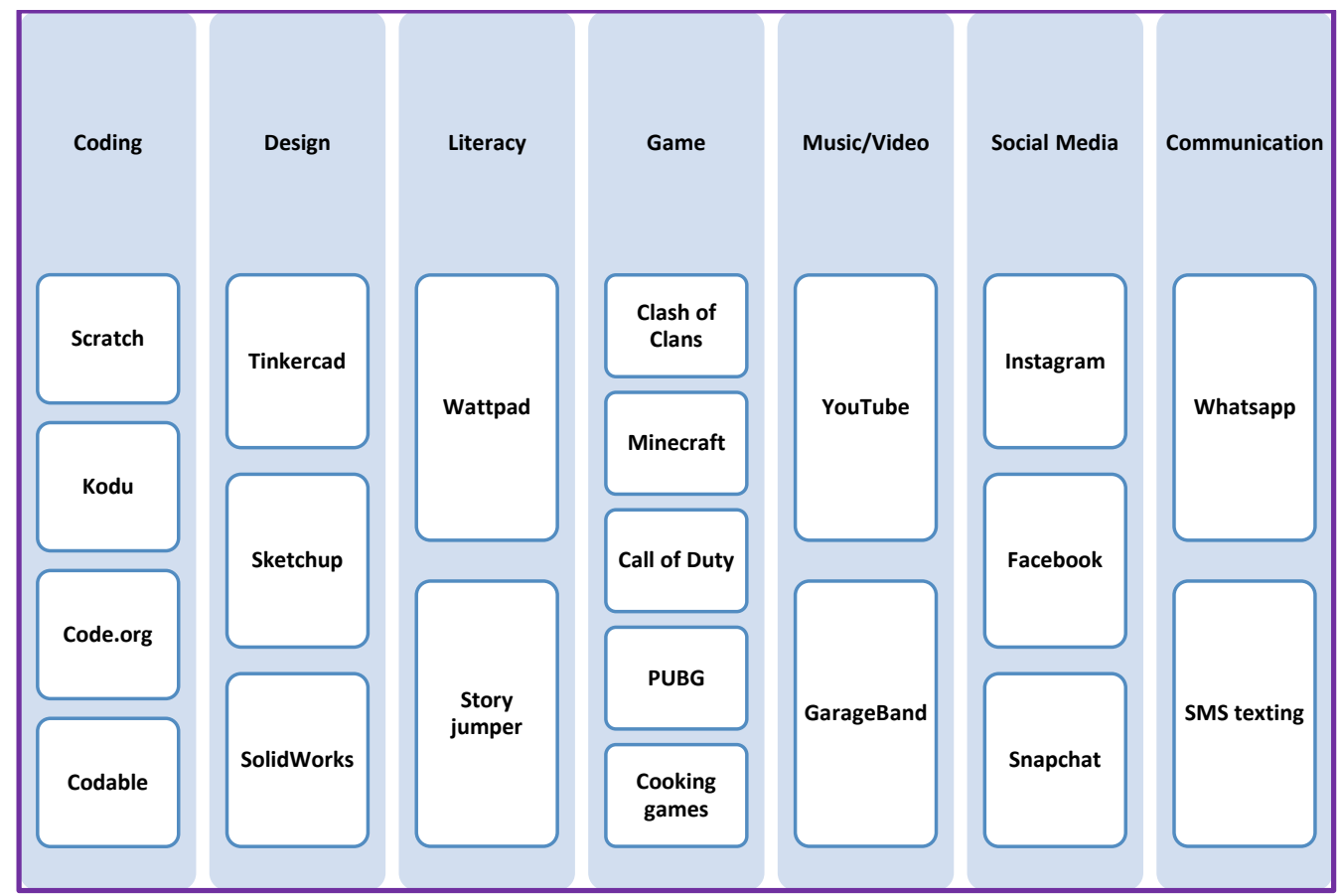

Figure 2. The types of programs/applications children use during interaction with the digital device

As seen in Figure 2, the categories of the types of digital apps and programs children use during interaction with their digital device are coding, design, literacy, 
game, music/video, social media and communication. The titles of the programs and applications that children shared for coding category are Scratch, Kodu, Code.org, Codable; for design category are Tinkercad, Sketchup, SolidWorks; for literacy category are Wattpad and Story jumper; for game category are Clash of Clans, Minecraft, Call of Duty, PUBG, Cooking games; for music/video category are YouTube, GarageBand; for social media category are Instagram, Facebook and Snapchat; and for communication category are WhatsApp and SMS texting. During the interview sessions the children were encouraged to talk about their favourite digital apps and programs that take up their time most, to find out the factors motivating them to be involved in that specific digital app or programme. Their explanations indicate that the ability in certain subjects makes them successful in performing it and being successful motivates them to perform better. This creates a cycle that ends with an increased interest which may result with long hours being busy with the digital device. In the study group, C2 affirmed this as follows: ' The Technology $\mathcal{E}$ Design course helps me to think in a different way. I like this. My teacher says I have a talent for design. I find creative ideas I don't know how... and try them on Tinker cad. When the teacher praises me, I'm motivated and I try to be more creative. It's fun.' Besides the ability factor, children accounted for their enthusiasm during their interaction with their digital devices. They highlighted the pleasure of transforming the code lines of a software program which have no distinct meaning into a goal-oriented implementation; the pleasure of designing 3D models and see that their project ideas become real and the pleasure of learning new and challenging subjects. Participant C5 expressed this by saying 'I like to see my codes working on the screen. I come up with new ideas and want to write a computer programme all day. Game coding is even more fun.' Another motivation of children for spending time with a digital device is being in touch with their friends and being aware of what's happening in the life of the people they follow on social media. Participant C63 said, 'I don't use computer or tablet. But I cannot live without my phone. If I'm awake that means I use my phone... Any of my friends can write a message at any moment. So, I'm online all the time. If I'm alone I sometimes surf the web, stalk some Instagram accounts. If I'm with my friends we do it together, then talk about the accounts we stalked. Sometimes we inform each other about an interesting account and make comment on it. The time passes so quickly with my phone.'

Based on the interview transcripts, the purpose of the children for their use of digital devices are categorised as shown in Figure 3. 


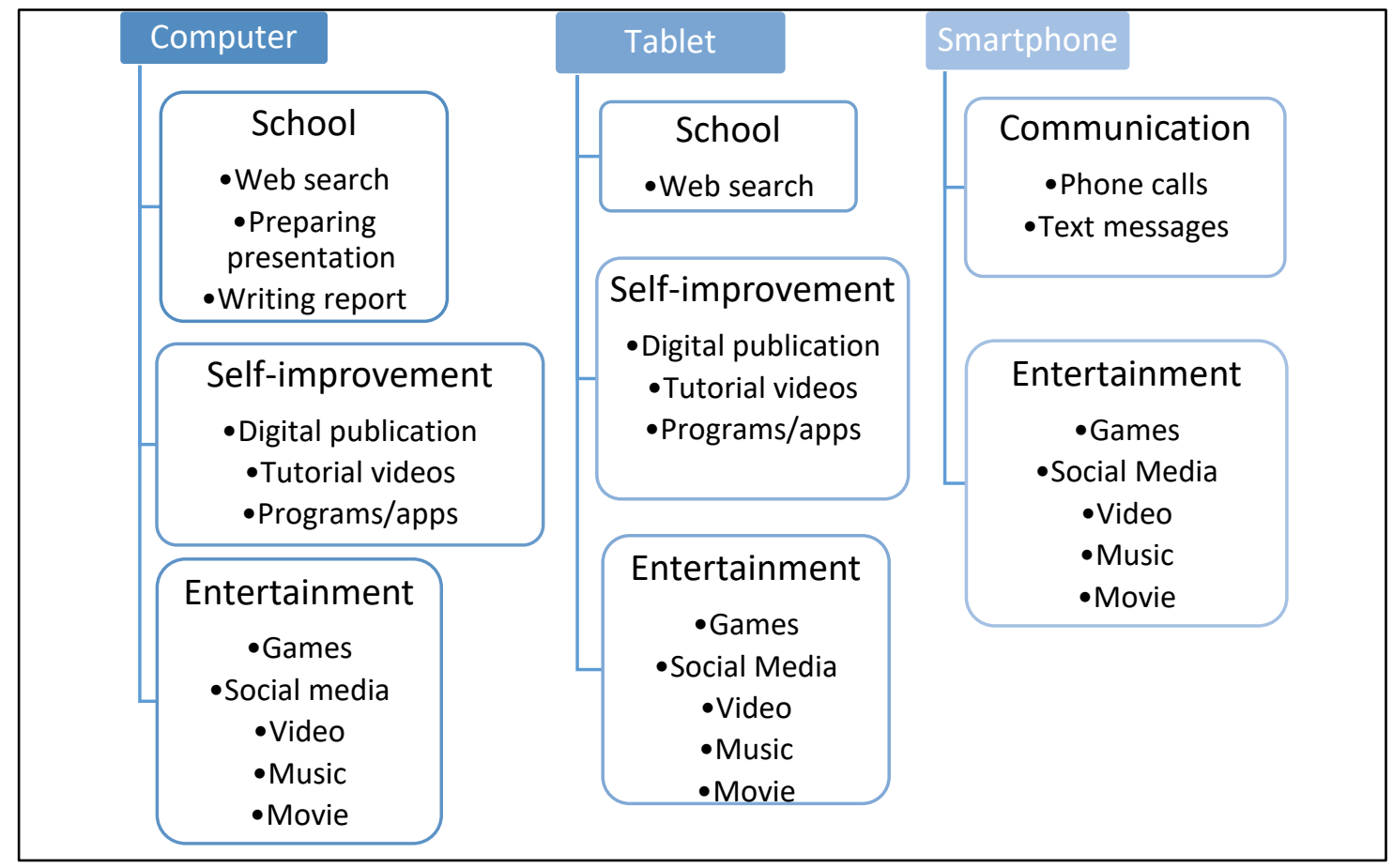

Figure 3. Children's purposes in using digital devices

Figure 3 shows that the children's purpose for computer and tablet usage falls under three categories, while their purpose for smartphone usage falls under two categories. The former are school, entertainment, and self-improvement, while the latter are communication and entertainment. For three of these main categories, school contains three subcategories for computer use which are web search, preparing presentations and writing reports while it contains one subcategory for tablet use that is the web search. The subcategories of the self-improvement category are digital publication, tutorial videos and programs and apps. As for the purpose of computer and tablet use the subcategories of the entertainment category are games, social media, video, music, and movies for computer use and drawing, design and coding for tablet use. Concerning the purpose of smartphone use, the communication category contains two subcategories which are phone calls and text messages while the subcategories under the entertainment category are games, social media, video, music and movie similar with computer and tablet use.

The children were asked first 'How do you feel while using your computer/tablet/smartphone?' and then 'How do you feel when you don't have access to your computer/tablet/smartphone?'. The results are recorded in Figure 4 below. 


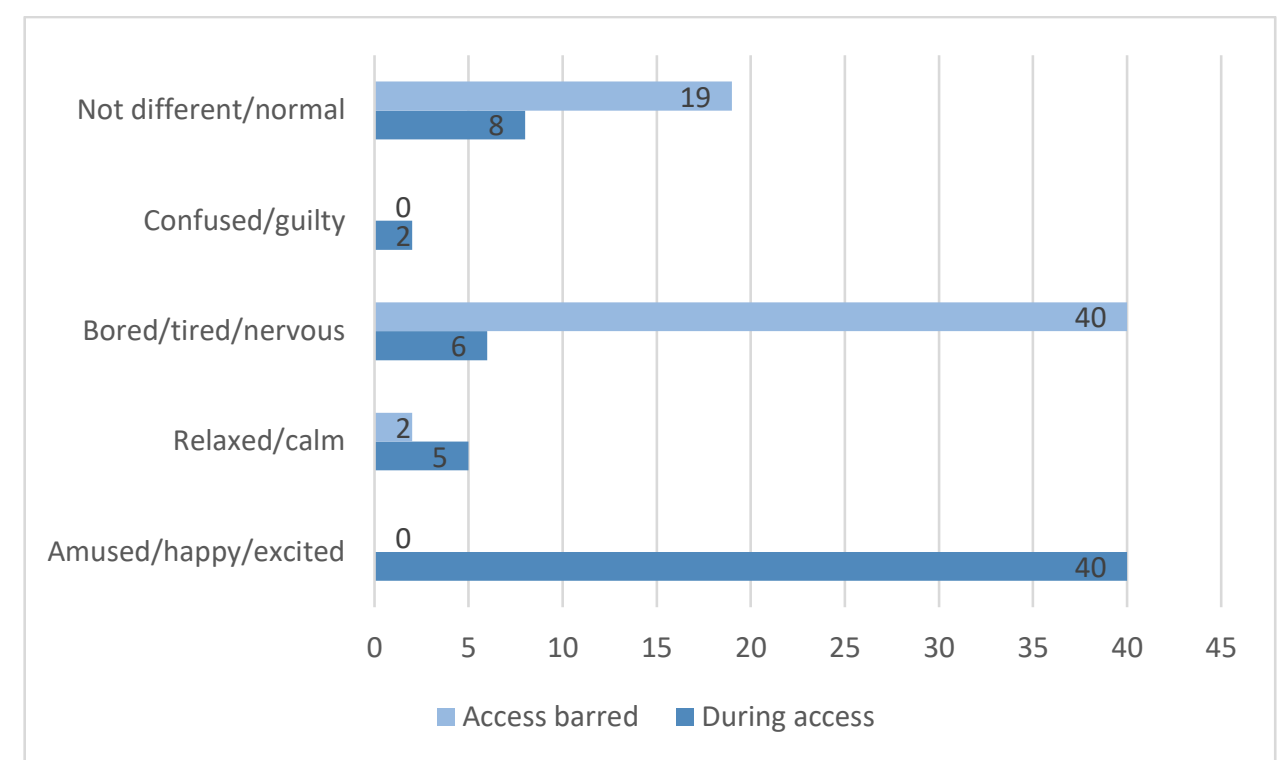

Figure 4. Children's emotions while using their computer/ tablet/ smartphone and in case of noaccess.

Figure 4 shows most of the children (40) indicated that they felt positive, as if they were amused, happy, and excited; 8 of the children feel no differently than before; 6 of them get bored, tired or nervous after a time; 5 of them feel relaxed and calm after completing a task, and two feel guilty or confused for using their digital device. To the question 'How do you feel when you don't have access to your computer/tablet/smartphone?', the majority of the children (40 of 61) responded that it would make them nervous or bored. On the other hand, 19 of them answered that 'I wouldn't feel its absence/I would substitute an alternative'. Two of the children complained about their screen time and stated that they considered it as an opportunity to end the dominance of their digital devices in daily routines. Some of the children underlined that they were not addicted to their digital devices and would always find alternative activities. C26 said 'If I did not have access to my digital devices, I would spend more time on outside activities, drawing or playing with my toys. My computer is not my everything.' which shows his conscious level of responsible consumption. Some of the children (C16, C30) stated that they had already experienced that feeling during a power failure or when the computer was out of order. They noted that they turned this into an opportunity to spend more time with family or friends. Some of the children, on the other hand, relied on boredom. C24 expressed by saying that 'Without my computer, I would go crazy, I guess. When I'm not online I go crazy and keep after my mom about what to do.' Some children explained their reason for being unhappy logically. C5 said 'I feel unhappy if I can't use my computer or smartphone because I use them to contact my friends abroad. If I can't use them, I will lose my communication, so I miss my friends and this makes me unhappy.' These words illustrate the contributions of technology usage to his life and his emotional. 


\section{Discussion, Conclusion and Recommendations}

The findings in this study, which aims to investigate the diversity of the characteristics of technology use by children reveal that the sophisticated use of digital devices evince high-level consciousness in using technology, not only for entertainment or socialization but also for numerous other activities such as robotics, coding, and design. The focus of the children with this aim, is on transforming their interest in selfimprovement. This helps children to acquire a scientific standpoint using technology for productive skills instead of killing time on the Internet. On the other hand children using technology with no specific intension of any sophisticated use prefer to spend their time longer than recommended limits mostly being busy with social media. Kaspersky Lab Report (2017) shows that there is a diversity of purposes for computer and internet use of children in the world and it is parallel with the findings of this study.

Some studies address the risks of technology use along with its benefits. A number of research results agree that children use their computers mostly for entertainment. Fuchs and Woessmann (2004) claim a negative correlation between school success and computer gaming or Internet use. The results of Foen, Zakaria, Lai and Confessore (2016) are in line with their study. Samuelsson's study of Swedish children (2010) revealed that the purpose of IT use among 13-year-old children is mostly fun. This study determined that children in the study group use their computers, tablets and smartphones for entertainment as well as for other purposes such as school, self-improvement and communication. This result implies that introducing children to productive ways of using technology helps them overcome the negative effects of misuse or overuse. At this point, the emphasis should be on the mission of the parents and teachers to create a vision for the beneficial use of technology. The results of this study suggest that the children can achieve the sophisticated use of technology if they are guided appropriately.

When the duration of the children's exposure time to a computer, tablet or smartphone is analysed, the numbers show that the majority of the children spent 1-2 hours with computers, less than an hour with tablets and more than three hours with smartphones. The statistics of TUIK in 2013 showed that the majority of children (48.7 \%) between 6-15 years old in Turkey allocated 0-2 hours in a day for TV (TUIK, 2014) and $19 \%$ of them reported that they spend less time watching TV to allocate more time for Internet. It seems that over time, mobile technologies have replaced TV for the new generation. Since the reports referred above and the more recent reports of TUIK for 2019 do not present the statistics for the duration of technology use specifically for children it is not possible to make regional comparisons on a global scale. For a local comparison from the same region, in their study Aktaş, Balkan and Karapinar (2009) reported that children preparing for matriculation allocate 170 minutes per day for Internet use. This period is longer than the results of this study for screen time. Taking into consideration that their study was conducted using an older age group, the increase in average age may help explain the rise in duration allocated for digital devices. For a global comparison the Digital 2019 report by We Are Social reveals 6 hours 42 minutes of world average for daily Internet use which is above the results of this study. This can be explained in relation to the participants who use their digital devices responsibly and try to limit their own excessive usage. 
In this study, for a deeper understanding beyond the statistics of duration about technology use by children, the participants were encouraged to share their feelings while using their computer, tablet or smartphone. The majority of children reported feeling happy and excited during use. When unable to find an opportunity to use any of these devices, the same number declared that they would become nervous or bored and feel the absence of their device in their lives. This second group's feelings support what lies beneath the concerns of parents, teachers, and researchers, and it is necessary to take concrete steps to address these concerns, since technology addiction can become a risk even among a group of children with this level of consciousness about the use of technology. Almost one third of the participant children shared that it was not a big problem to compensate the access barred by performing other activities. Parents and educators need programmes that meet the requirements of twenty-firstcentury children. These should be designed by experts knowledgeable about the effective use of technology among children because only conscious adults can raise the awareness of children for the purposeful use of technology.

This study has some limitations. The first one is, it is limited to its sample size. Although the number of participants is not enough to make generalisations on the subject, it gives an idea about the motivation sources of the children who can achieve the sophisticated use of their digital devices. Another limitation is the reliability of the data collected from the children and their parents. The data of the study are collected by the information form received from the families, a survey received from the participants and the sharing of children during the interview. The information given by the parents and the children and the statements of the children is considered to be correct. It is believed that the conclusions drawn from the findings of this study by considering their limitations will be evaluated by the researchers to direct them for further studies.

Technology use is on the rise and is expected to become more widespread over time. Studies on the adoption of technology among children have shown there are two sides to the use of devices. Children benefit from computers, tablets, and smartphones as an educational aid, as well as a means of socialization and gaming or entertainment. This extensive usage, however, is also a source of anxiety because of the possible negative effects, especially on children. The purpose, duration and quality of the exposure are critical to obtaining positive results. Using technology for purposes such as design, coding or robotics, utilizing qualified tools with these aims in mind, and ensuring this usage appropriate for the requirements of each age group will help suppress concerns and increase efficiency. Developing expedient programmes with these goals may help children become productive and more mindful about possible problems. However, despite the productive purpose of these devices, unlimited use comes with some physical and emotional deficits. Children should not only be acquainted with the risks of excessive technology use and precautions taken to that effect but also be guided until they form a habit of appropriate behaviour. The first suggestion of the study is for policymakers to establish programmes that supervise the effective use of technology attainable for every child since the research results show that appropriate programmes make a difference in the beneficial use of technology. The second suggestion is for researchers to develop appropriate programmes for each age range that will motivate children to be productive when using emerging 
technologies. The final suggestion is for parents and teachers to be aware of this modern-day phenomenon and to educate themselves about how to best supervise their children. To that end, more research is necessary to clarify the positive and negative effects of technology use by children and to broaden the vision of all partners in education towards optimum outcomes of technology use. The contribution of this paper to the literature is underscoring the importance and giving an in-depth understanding of technology use among children by determining the distinct characteristics and interests of them and the circumstances that lead them to be techproducers or consumers; providing recommendations to researchers to determine a framework, to policymakers to prepare laws based upon that framework, and to teachers and parents to guide children in the beneficial uses of technology.

\section{References}

Aktaş, E., Balkan, B., ve Karapınar, K.(2009). Biga'da bilim teknolojileri kullanımının öğrencilerin başarı ve harcama düzeylerine olası etkileri. Kocaeli Üniversitesi İktisadi ve İdari Bilimler Fakültesi Dergisi, 5(7), 39-48. Retrieved from https://www.researchgate.net/profile/Erkan_Aktas/publication/48376290_ Biga'da_Bilisim_Teknolojileri_Kullaniminin_Ogrencilerin_Basari_ve_Harcama _Duzeylerine_Olasi_Etkileri/links/544011150cf2be1758cff918.pdf

Altun, D. (2018). The efficacy of multimedia stories in preschoolers' explicit and implicit story comprehensio. Early Childhood Education Journal

Aral, N., and Doğan Keskin, A. (2018). Examining 0-6 year olds' use of technological devices from parents' points of view. Addicta: The Turkish Journal on Addiction, 5, 177-208.http:/ /dx.doi.org/10.15805/addicta.2018.5.2.0054

APA Task Force On Violent Media (2015). Technical Report on the Review of the Violent Video Game Literature, Retrieved from http:/ / www.apa.org/pi/families/violent-media.aspx

Aydin, B. (2017). Three birds with a stone: Technology integration in language education. Journal of Teacher Education and Educators, 6(2), 177-190.

Beetham, H., and Sharpe, R. (2007). Rethinking pedagogy for a digital age: designing and delivering e-learning. Routledge Publishing, NY.

Blum-Ross, A., and S. Livingstone (2016) Families and screen time: Current advice and emerging research. Media Policy Brief 17. London: Media Policy Project, London School of Economics and Political Science.

Briggs, C. (1986). Learning how to ask: A sociolinguistic appraisal of the role of the interview in social science research. Cambridge: Cambridge University Press.

Choi, K., and Kirkorian, H. (2016). Touch or watch to learn? Toddlers' object retrieval using contingent and noncontingent video. Psychological Science, 27(5), 726-736. doi: $10.1177 / 0956797616636110$

De Jong, M.T., and Bus, A.G. (2004). The efficacy of electronic books in fostering kindergarten children's emergent story understanding. Reading Research Quarterly, 39(4), 378 -393. doi: 10.1598/RRQ.39.4.2

Dejonckheere, P.J.N., Desoete, A. , Fonck, N., Roderiguez, D., Six L., Vermeersch, T., and Vermeulen, L. (2014). Action-based digital tools: Mathematics learning in 6-year-old children. Electronic Journal of Research in Educational Psychology, 12(1), 61-82. doi:10.14204/ ejrep.32.13108 
Fessakis, G., Gouli, E., and Mavroudi, E. (2013). Problem solving by 5-6 years old kindergarten children in a computer programming environment: A case study. Computers E Education, 63, 87-97. doi: 10.1016/j.compedu.2012.11.016

Foen, S.N., Zakaria, R., Lai, S. M. and Confessore, G.J. (2016). A study of time use and academic achievement among secondary-school students in the state of Kelantan, Malaysia. International Journal of Adolescence and Youth, 21(4), 433448. doi:10.1080/02673843.2013.862733

Fuchs, T. and Woessmann, L. (2004). Computers and student learning: Bivariate and multivariate evidence on the availability and use of computers at home and at school, CESIFO Working Paper No:1321. Retrieved from https:/ / ssrn.com/abstract $=619101$

Hilda K., Kabali, H.K., Irigoyen, M.M., Nunez-Davis, R., Budacki, J.G., Mohanty, S.H., Leister, K.P., and Bonner, R.L. (2015). Exposure and use of mobile media devices by young children. Pediatrics, 136(6), 1044-1050. doi: $10.1542 /$ peds.2015-2151

Hoshmand, L. T. (1989). Alternate research paradigms: A review and teaching proposal. The Counseling Psychologist, 17(1), 3-79. doi:10.1177/0011000089171001

Kaspersky Lab Report (2017). Kaspersky Lab's Latest Prental Control Report. Retrieved on April, 24, 2018 from https:/ / www.kaspersky.com/about/pressreleases/2017_kaspersky-labs-latest-parental-control-report-shows-howdifferent-children-are-around-the-world

Koçak, Ö., Yılmaz, R. M., Küçük, S. and Göktaş, Y. (2019). The educational potential of augmented reality technology: Experiences of instructional designers and practitioners. Journal of Education and Future, 15, 17-36.

Lips, M., Eppel, E., McRae, H., Starkey, L., Sylvester, A., Parore, P. and Barlow, L. (2017). Understanding children's use and experience with digital technologies: Final research report. Retrieved on April 20, 2018 from https://www.victoria.ac.nz/_data/assets/pdf_file/0003/960177/Understan ding-children-use-and-experience-of-digital-technologies-2017-v2.pdf

McPake, J., Plowman, L., and Stephen, C. (2013). Pre-school children creating and communicating with digital technologies in the home. British Journal of Educational Technology, 44(3), 421-431. doi: 10.1111/j.1467-8535.2012.01323.

Mills, K. (2011). 'I'm making it different to the book': Transmediation in young children's multimodal and digital texts. Australasian Journal of Early Childhood, 36(3), 56-65.

Neumann, M.M., and Neumann D.L. (2014). Touch screen tablets and emergent literacy. Early Childhood Education Journal, 42, 231-239. doi:10.1007/s10643-013-

OECD (2012). The Protection of Children Online. Retrieved on April 14, 2018 from https://www.oecd.org/sti/ieconomy/childrenonline_with_cover.pdf

Özdemir, S., Çetin, E., Çelik, A. Berikan, B., and Yüksel, A.O. (2017).Furnushing new generations with productive ICT skills to make them the maker of their own future, Journal of Education and Future, 11, 137-157

Patton, M.Q. (2014) Nitel Araştırma ve Değerlendirme Yöntemleri, (Trans.Ed: Bütün, M., Demir, S.B.) Pegem Akademi, Ankara. 
Periathiruvadi, S. and Rinn, A.N. (2012). Technology in gifted education: A review of best practices and empirical research. Journal Of Research on Technology in Education, 45(2), 153-169. doi: 10.1080/15391523.2012.10782601

Samuelsson, U. (2010) ICT use among 13-year-old swedish children, Learning, Media and Technology, 35(1), 15-30. doi: 10.1080/17439880903560936

Sheehan, K. J., and Uttal, D. H. (2016). Children's learning from touch screens: a dual representation perspective. Frontiers in Psychology, 7, 1220. doi:10.3389/fpsyg.2016.01220

Shieh, C., and Yu, L. (2016). A Study on Information Technology Integrated Guided Discovery Instruction towards Students' Learning Achievement and Learning Retention. Eurasia Journal of Mathematics, Science and Technology Education, 12(4), 833-842. https:/ / doi.org/10.12973/eurasia.2015.1554a

Simpson, A., Walsh, M., and Rowsell, J. (2013). The digital reading path: researching modes and multidirectionality by tablets. Literacy, 47(3), 123-130. doi:10.1111/lit.12009

Sutton, J., and Austin, Z. (2015). Qualitative research: Data collection, analysis, and management, The Canadian Journal of Hospital Pharmacy, 68(3), 226231. Retrieved from https://www.ncbi.nlm.nih.gov/pmc/articles/PMC4485510/

Torsheim, T., Eriksson, L., Schnohr, C. W., Hansen, F., Bjarnason, T., and Välimaa, R. (2010). Screen-based activities and physical complaints among adolescents from the Nordic countries. BMC Public Health, 10(324). Retrieved from http:/ / www.biomedcentral.com/1471-2458/10/324.

TÜİK (2014). İstatistiklerle Çocuk, Ankara , Türkiye İstatistik Kurumu Matbaası UNESCO. (2017). International Forum on ICT and Education 2030. Retrieved on April, 18, 2018 from http:/ / unesdoc.unesco.org/images/0025/002595/259587e.pdf

Wainwright, D. K., and Linebarger, D. L. (2009). Television can teach: Elements of effective educational television. In N. N. Nagaraj(Ed), Effect of Television on Children (pp. 24-44). Hyderabad, India: Icfai University Press.

Ward, J.H. (2012). Managing Data: Content Analysis Methodology. Unpublished

Manuscript, University of North Carolina at Chapel Hill. Retrieved May 7, 2019 from https://www.impactzone.co/wp-content/uploads/2016/05/final-ca-lr-jhwupdated-compressed.pdf

We Are Social. (2018). Global Digital Report 2018. Retrieved April 25, 2018 from https:/ / digitalreport.wearesocial.com/

We Are Social. (2019). Global Digital Report 2019. Retrieved March 5, 2020 from https:/ / www.digitalinformationworld.com/2019/02/internet-users-spendmore-than-a-quarter-of-their-lives-online.html

Vesisenaho, M., Dillon, P., Havu-Nuutinen, S., Nousiainen, T., Valtonen, T., and Wang, R. (2017). Creative improvisations with information and communication technology to support learning: A conceptual and developmental framework. Journal of Teacher Education and Educators, 6(3), 229250.

Wiecha, J., Peterson, K., Ludwig, D., Kim, J., Sobol, A. and Gortmaker, S. (2006). When children eat what they watch: Impact of television viewing on dietary 
intake in youth. Archives of Pediatrics and Adolescent Medicine. 160(4), 436-42. doi:10.1080/17439880903560936

Yaman, F., Dönmez, O., Kabakçı Yurdakul, I., and Odabaşı, H.F. (2017). Primary school students' encounters against online risks from the perspectives of schools counselor teachers. Turkish Online Journal of Qualitative Inquiry (TOJQI), 8 (4), 415-427.

Yelland, N.J. (2018). A pedagogy of multiliteracies: Young children and multimodal learning with tablets. British Journal of Educational Technology, 49(5), 847-858.

Yıldırım, A. ve Şimsek, H. (2016). Sosyal Bilimlerde Nitel Araştırma Yöntemleri, Ankara, Seçkin Yayıncılık.

Yücelyiğit, S., and Aral, N. (2013). The effects of 3d animated movies and interactive applications on development of visual perception in 60-72- months-old children. International Journal of Online Pedagogy and Course Design, 3(3), 101108. doi:10.4018/ijopcd.2013070107

Yücelyiğit, S., and Aral, N. (2016). The effects of three dimensional (3D) animated movies and interactive applications on development of visual perception of preschoolers. Education and Science, 41(188), 255-271. doi: 10.15390/EB.2016.6743

Yücelyiğit, S., and Aral, N. (2017a). Three dimensional animated movies, touch screen interactive applications and visual motor development of five-year- old children. International Journal of E-Adoption, 9(1), 1-10. doi: 10.4018/IJEA.2017010101

Yücelyiğit, S., and Aral, N. (2017b). STEM education in child development. In R. Efe (Ed.) Developments in Health Sciences (pp. 405-410), Sofia, St. Kliment Ohridski University Press.

\section{Araştırmanın Etik Taahhüt Metni}

Yapılan bu çalışmada bilimsel, etik ve alıntı kurallarına uyulduğu; toplanan veriler üzerinde herhangi bir tahrifatın yapılmadığı, karşılaşılacak tüm etik ihlallerde "Cumhuriyet Uluslararası Eğitim Dergisi ve Editörünün” hiçbir sorumluluğunun olmadığı, tüm sorumluluğun Sorumlu Yazara ait olduğu ve bu çalışmanın herhangi başka bir akademik yayın ortamına değerlendirme için gönderilmemiş olduğu sorumlu yazar tarafından taahhüt edilmiştir.

\section{Authors' Biodata/ Yazar Bilgileri}

Secil Yucelyııt Dr. Seçil Yücelyiğit received her bachelor's degree on mathematics from Hacettepe University Department of Mathematics in 1997 and earned her Ph.D. degree from Ankara University Child Development and Education Program in 2014. She focused on early childhood education and technology integration in children's education. She has many practice books on early childhood education and a number of book chapters and articles published in both national and international indexed journals about her focus area. She is a faculty member of TED University at Faculty of Education, Early Childhood Education Program.

Seçil YÜCELYİĞİT, 1997 yılında Hacettepe Üniversitesi Matematik Bölümü'nden matematik alanında lisans derecesini ve 2014 yılında Ankara Üniversitesi Çocuk Gelişimi ve Eğitimi Programı'ndan doktora derecesini aldı. Erken çocukluk eğitimi ve 
çocukların eğitiminde teknoloji entegrasyonuna odaklandı. Erken çocukluk eğitimi konusunda çok sayıda uygulama kitabı ve çalışma alanı ile ilgili ulusal ve uluslararası indeksli dergilerde yayınlanmış çok sayıda kitap bölümü ve makalesi bulunmaktadır. TED Üniversitesi Eğitim Fakültesi Okul Öncesi Eğitim Programı öğretim üyesidir.

Neriman Aral Prof. Neriman Aral gained her master's degree in 1986 from Hacettepe University. She has two doctorate degrees one of them from Ankara University (1990) and other one from Hacettepe University (1992). She became an associate professor at Ankara University in 1995 and professor in 2001. She has made observations for three months at the University at Buffalo the State University of New York, Institute of Education Department of Learning and Teaching Early Years and Childhood as a guest researcher. Prof. Aral took part in the projects supported by European Union, TUBITAK and University resources. She has many articles in international and national journals, many books and books chapters on child development. She is a faculty member of the Health Sciences Faculty of Ankara University and serving as dean since 2017 at the same faculty.

Neriman ARAL, 1986 yılında Hacettepe Üniversitesi'nden yüksek lisans derecesini ald1. Biri Ankara Üniversitesi'nden (1990), diğeri Hacettepe Üniversitesi'nden (1992) olmak üzere iki doktora derecesine sahiptir. 1995 yılında Ankara Üniversitesi'nde doçent, 2001 y1lında profesör oldu. University at Buffalo the State University of New York, Institute of Education Institute of Learning and Teaching Early Years and Childhood Bölümü'nde misafir araştırmacı olarak üç ay süreyle gözlem yaptı. Aral, Avrupa Birliği, TÜBİTAK ve Üniversite kaynakları tarafından desteklenen projelerde yer aldı. Uluslararası ve ulusal dergilerde çok sayıda makalesi, çocuk gelişimi ile ilgili çok sayıda kitap ve kitap bölümü bulunmaktadır. Ankara Üniversitesi Sağlık Bilimleri Fakültesi öğretim üyesi olup, 2017 yılından itibaren aynı fakültede dekan olarak görev yapmaktadir. 